\title{
O SETOR DE FRANCÊS
}

\author{
Eunice Dutra Galery \\ UFMG
}

\begin{abstract}
Setor de Francês da FALE... Na verdade, o começo foi bem antes, ainda na FAFICH, com catedrático - Prof. Orlando de Carvalho - e tudo. Como quem nasce no forno costuma ser biscoito, havia franceses professores, Jean Vincent, Marcel Debrot (se bem que este último fosse suíço), franceses leitores, Damien Saunal, Boëlly, Claude Cade, Monique Imbert (que, improvisando, dava aulas com a filha pequena no colo. À medida que escrevia no quadro, a mãozinha da menina apagava, até que uma aluna, em desespero de causa, se sacrificava em favor da turma, pegava a pequetita e ia passear com ela, fora da sala de aula), Monique Bernard, que fez amigos e deixou saudades, Nicolas Tabuteau, François Folliot - e a plebe rude, ou seja, nós, os brasileiros: José Nogueira Starling, de muito saudosa memória; Carlos Maciel da Cunha, Cleonice Paes Barreto Mourão, Consuelo Fortes Santiago, Eliana Scotti Muzzi, Isis Vincent (que ocasionou uma séria revolução, ao se casar com o Vincent pai e, após a morte deste, com o filho, gerando uma árvore genealógica sui-generis, como se pode imaginar; na ocasião, era saudada sempre com os versos de Racine: "fille de Minos et Pasiphaé..." - a bom entendedor...), Laura Galery, com sua risada estrondosa, "acusada" de rachar o prédio da rua Carangola e nos fazer ir buscar pouso na Escola de Medicina, durante um semestre, Loamy Colares da Fonseca, Maria Cristina Esteves, Teresinha Lopes da Costa e esta escriba que, quando chegou para trabalhar, não tinha pouso nem mesa...

Ainda nos pagos do sétimo (mais metade do sexto) andar do "prédio da Fafich", a Faculdade de Letras dava seus primeiros passos. Ali se deram os primórdios do CENEX, que nem assim se chamava: eram os cursos audiovisuais de línguas modernas, introduzidos através das aulas de francês, primeiro setor a oferecer cursos regulares para a comunidade - idéia de Maria Magdalena Lana Gastelois, que já trouxera a novidade para o antigo Colégio Universitário. Em seguida, o setor fundou o Laboratório de tradução, ao qual se juntaram os outros setores de línguas da FALE. Após algum tempo, vieram os cursos de Francês Instrumental, que alguns pensavam tratar-se de instrumentos musicais! Brincadeiras à parte, foram grandes colaborações do Setor de Francês para o aperfeiçoamento do ensino e dos serviços prestados pela Faculdade de Letras da UFMG, não apenas à comunidade universitária, mas a toda a comunidade de Belo Horizonte.

Finalmente, na década de 1980, a grande mudança para o campus da Pampulha.

Acostumados que estávamos a trabalhar todos juntos, em uma grande sala, pareceunos um luxo extraordinário, quando da vinda para o prédio definitivo, ter um gabinete para cada dois professores. Verdade seja dita, o luxo ficou um pouco triste, nem sempre víamos os colegas, fechados em suas respectivas salas, o setor fracionado...
\end{abstract}


À medida que os professores mais antigos se aposentavam, novos vieram continuar o trabalho, com brilho e coragem: Beatriz Vaz Leão, Dilma Castelo Branco Diniz, Ida Lúcia Machado, Márcia Arbex, Maria Lúcia Jacob Dias de Barros, Renato Melo e, como já saí de lá há muito tempo, se houver mais alguém, que me perdoe.

A 